\title{
Social and emotional development of students with gifts and talents
}

Tracy L. Cross

College of William and Mary, tlcross@wm.edu

Lori Andersen

College of William and Mary

Sakhavat Mammadov

College of William and Mary, smammadov@email.wm.edu

Jennifer Riedl Cross

College of William and Mary, jrcross@wm.edu

Follow this and additional works at: https://scholarworks.wm.edu/educationbookchapters

Part of the Gifted Education Commons

\section{Recommended Citation}

Cross, Tracy L.; Andersen, Lori; Mammadov, Sakhavat; and Cross, Jennifer Riedl, "Social and emotional development of students with gifts and talents" (2017). School of Education Book Chapters. 14. https://scholarworks.wm.edu/educationbookchapters/14

This Book Chapter is brought to you for free and open access by the School of Education at W\&M ScholarWorks. It has been accepted for inclusion in School of Education Book Chapters by an authorized administrator of W\&M ScholarWorks. For more information, please contact scholarworks@wm.edu. 


\title{
CHAPTER 5
}

\section{Social and Emotional Development of Students With Gifts and Talents}

\author{
Tracy L. Cross, Lori Andersen, \\ Sakhavat Mammadov, and Jennifer Riedl Cross
}

Understanding that children have an inner life means acknowledging "a person's experience is what the world is to that person." -Coleman \& Cross (2000, p. 211)

\section{Essential Questions to Guide the Reader}

1. What common characteristics of children with gifts and talents affect their social and emotional development?

2. How do the interactions of these students with their environment affect their social and emotional development?

3. How does the lived experience of students with gifts and talents affect their social and emotional development?

This chapter focuses on the social and emotional development of students with gifts and talents by illustrating the relationship between characteristics and their interaction in different contexts. From the lived experiences of this combination of relationships, a gifted student's life becomes idiosyncratic, so to depict his social and emotional development requires information about three things: characteristics (endogenous), interaction of the characteristics with the environment (exogenous), and the lived experience. 
Cohen, Onunaku, Clothier, and Poppe (2005) described healthy social and emotional development as "a child's developing capacity to experience, manage and express the full range of positive and negative emotions; develop close, satisfying relationships with other children and adults; and actively explore their environment and learn" (p. 2). Social and emotional development represents the changes over time of two separate but related constructs that reflect characteristics, interactions, interpretations, and related behaviors in the lives of people that lead them to becoming adults. It includes the awareness, interpretations, and regulations of stimuli and events. As people develop, they become increasingly sophisticated and versatile when dealing with social and/or emotional experiences. In some cases, gifted children have unique characteristics and interactions with others, both of which may lead to unexpected interpretations and behaviors. In this chapter, we will describe theories and research that can help put the social and emotional development of gifted children into perspective.

\section{Psychosocial Development}

No person develops in a vacuum. Each one is the product of biology (nature) and experiences (nurture). Erikson (1963) proposed that psychological development progresses stage-like through a person's interactions with others. Erikson's theory of psychosocial development describes the challenges or crises people living in Western societies face across the lifespan. The lifespan emphasis of his theory was quite unique for its time. At each stage of life, people experience similar crises (see Table 5.1). If satisfactorily resolved, a person incorporates the lessons learned into her personal repertoire and successfully moves to the next level. If not, the issue can create challenges for the individual across his life. As humans, gifted individuals face these crises just as their peers do. From them, they internalize who they are in the social world.

All students must grapple with these psychosocial crises as described by Erikson (1963). As gifted young people experience each stage, they will face situations similar to those of their peers. However, their exceptional abilities may make some issues more difficult. For example, the verbally precocious 2 -year-old may be ready to take more initiative than adults may expect, creating strife and possibly guilt in the child who progresses through the stages earlier than her peers. Likewise, the gifted young person with multipotentiality may experience more role confusion than his average peers. It may be more difficult for gifted young people to find intimacy among their nongifted peers, leading to a greater sense of isolation. It can be useful to consider each of Erikson's stages when planning instruction or engaging in formal or informal counseling with gifted young people or their caregivers.

Erikson's (1963) theory of psychosocial development offers an explanation for how circumstances (crises) individuals face can affect their social and emotional 
Table 5.1

Erikson's Stages of Psychosocial Development (Erikson, 1963)

\begin{tabular}{|l|l|}
\multicolumn{1}{|c|}{ Approximate Age } & \multicolumn{1}{c|}{ Crisis to Be Resolved } \\
\hline $0-1 \frac{1 / 2}{11 / 2-3}$ & Trust vs. Mistrust \\
$3-5$ & Autonomy vs. Shame and Doubt \\
$6-11$ & Initiative vs. Guilt \\
Adolescent & Industry vs. Inferiority \\
Early Adult & Identity vs. Role Confusion \\
Middle Adult & Intimacy vs. Isolation \\
Late Adult & Generativity vs. Stagnation \\
\hline
\end{tabular}

development. The malleable minds of gifted young people are being shaped by the experiences they have at each stage of development.

\section{Dabrowski's Theory of Positive Disintegration}

Another theory, Kazimierz Dabrowski's (1964) Theory of Positive Disintegration (TPD), has been widely regarded as having particular value in understanding the social and emotional development of gifted individuals. This theory explains differences in personality - a characteristic found within the person (endogenous) - that affect how people behave. Dabrowski created his TPD to explain differences in the behaviors of highly gifted and creative people, as well as the behaviors of ruthless leaders. Although most theories of advanced development primarily rely on intelligence, TPD relies on his definition of personality. He described personality as a psychological state that includes a personal value system and specific forces that drive behavior. He offered this as the explanation of why some people are more likely to achieve advanced personality development than others (development potential).

In the TPD, personality has five levels, as noted in Table 5.2. Primary integration is the lowest level, which is the starting point for everyone. Individuals at this level do not have their own value system and make decisions based on instinct or impulse. The development of a personal value system is a primary task of personality development and is called multilevelness. As individuals transition through Levels III and IV, they begin to consider other reasons for choices, such as how choices affect others. They are able to be more autonomous, act in accordance with personal ideals, and put these personal ideals above a need for societal approval or impulse. At the highest level, secondary integration, individuals live according to personal ideals. 
Table 5.2

Personality Levels in TPD

\begin{tabular}{|l|l|l|}
\hline \multicolumn{1}{|c|}{ Classification } & \multicolumn{1}{|c|}{ Level } & \multicolumn{1}{c|}{ Descriptions } \\
\hline Unilevel & I-Primary Integration & $\begin{array}{l}\text { Decisions are driven by impulse and } \\
\text { instinct. }\end{array}$ \\
\cline { 2 - 3 } & II-Unilevel Disintegration & $\begin{array}{l}\text { Decisions are driven by societal } \\
\text { expectations. }\end{array}$ \\
\hline \multirow{2}{*}{ Multilevel } & $\begin{array}{l}\text { III-Spontaneous } \\
\text { Multilevel Disintegration }\end{array}$ & $\begin{array}{l}\text { Decisions are driven by inner conflict } \\
\text { about bringing behavior up to an ideal. }\end{array}$ \\
\cline { 2 - 3 } & $\begin{array}{l}\text { IV-Organized Multilevel } \\
\text { Disintegration }\end{array}$ & $\begin{array}{l}\text { Through high levels of responsibility, } \\
\text { authenticity, reflective judgment, } \\
\text { empathy, autonomy, and self-awareness, } \\
\text { decisions are driven by inner forces and } \\
\text { values. }\end{array}$ \\
\cline { 2 - 3 } & V-Secondary Integration & $\begin{array}{l}\text { By living according to the highest, most } \\
\text { universal principles, self-actualization is } \\
\text { achieved. }\end{array}$ \\
\hline
\end{tabular}

Note. Adapted from The Theory of Positive Disintegration by Kazimierz Dabrowski by B. Tillier, 1995, http://www.positivedisintegration.com/10concepts.html\#ml.

The most important distinction between personality levels in TPD is multilevelness. For a unilevel personality, all personal choices seem to have equal value. A multilevel personality has an internal, hierarchical system of values that gives certain options higher values than others. Different forces, or dynamisms, dominate decisions at low and high personality levels. For low-level personality, decisions are driven by impulse and instinct, while for high-level personality, decisions are driven by inner voices and internal values. Dabrowski believed that only $35 \%$ of people achieved multilevelness and that multilevelness was more often present in highly gifted and creative people.

The Theory of Positive Disintegration explains how and why this development occurs. One difference between TPD and other developmental theories is that personality development is not universal; most people will not reach multilevelness. Dabrowski (1964) explained that personality development was a breakdown, or disintegration, of previously existing psychological structures that allowed the individual to examine his or her own values, emotions, and behavior. The phrase positive disintegration is used because the outcome of the disintegration process is a positive one-an advanced personality. Disintegration describes inner conflict and discontent with one's life compared to personal ideals. During disintegration, individuals experience distress and anxiety. A time period of disintegration is a natural part of the process of development.

Developmental potential explains why some people reach multilevelness and others do not. High developmental potential has three characteristics: (a) special 
abilities and talents, (b) certain overexcitabilities, and (c) a strong drive to be autonomous. Overexcitabilities, or responses to stimuli that are higher than average, occur in different sensory channels: emotional, imaginational, intellectual, psychomotor, and sensual. Table 5.3 provides a description of each type of overexcitability. (See Chapter 4 for additional information on overexcitabilities.)

Research findings regarding advanced developmental potential and gifted students are somewhat mixed (Mendaglio, 2012). Students with gifts and talents possess special abilities and talents, characteristic of developmental potential. However, comparisons of overexcitabilities in these learners with other students have had inconsistent findings. High intellectual ability does not generally coincide with high levels of intellectual overexcitability. This is probably not surprising to most teachers. Every teacher has likely observed students who have high cognitive abilities, but who are not passionate about intellectual pursuits. A student who has an intellectual overexcitability is one who derives pleasure from learning. Therefore, a student with high intellectual overexcitability is likely to be intellectually gifted, but not all intellectually gifted students will have high intellectual overexcitability.

Research on highly creative adults revealed stronger associations between creative and artistic talents and levels of emotional and imaginational overexcitabilities (Mendaglio \& Tillier, 2006). Fewer studies have investigated the developmental potential or personality levels of gifted children or adults. Most research in this area has focused on measuring the overexcitabilities and comparing gifted and nongifted groups (Tillier, 2009). However, the overexcitabilities are not the only indicator of developmental potential. The third characteristic of developmental potential, the drive to be autonomous, has yet to be studied.

Although the research base is weak, those who subscribe to the theory find explanations for the intensities they observe among gifted children and for the development of personal values and decision making. Gifted students may see similarities in their experience and Dabrowski's proposed overexcitabilities, the positive disintegration process, and personality development. Discussing the lives of highly gifted and creative individuals who exemplify multilevelness and exploring their overexcitabilities can help gifted students to accept and appreciate their own experiences and development. Knowledge of the positive disintegration process can help students make sense of their inner conflicts and feel less different from other people.

\section{Endogenous Characteristics}

The combination of Erikson's (1963) Theory of Psychosocial Development and Dabrowski's (1964) Theory of Positive Disintegration lead to understanding how a gifted child is developing an inner life, a sense of personal agency, locus of control, perspectives, and values that guide one's behavior. One must also consider a number 
Table 5.3

Overexcitabilities and Developmental Potential

\begin{tabular}{|l|l|l|}
\hline \multicolumn{2}{|c|}{ Overexcitability } & \multicolumn{1}{c|}{ Description } \\
\hline $\begin{array}{l}\text { Increases } \\
\text { developmental } \\
\text { potential }\end{array}$ & Emotional & $\begin{array}{l}\text { Intensity of feeling, strong affective } \\
\text { memory, anxiety, fear }\end{array}$ \\
\cline { 2 - 3 } & Imaginational & $\begin{array}{l}\text { Vivid imagery, invention, animated } \\
\text { visualization, metaphor, fantasy }\end{array}$ \\
\cline { 2 - 3 } & Intellectual & $\begin{array}{l}\text { Questioning, problem solving, theo- } \\
\text { retical thinking, sustained intellectual } \\
\text { effort, derives pleasure from intellectual } \\
\text { pursuits }\end{array}$ \\
\hline $\begin{array}{l}\text { Lowers } \\
\text { developmental } \\
\text { potential }\end{array}$ & Psychomotor & $\begin{array}{l}\text { High degrees of energy, pursuits of } \\
\text { intense physical activity }\end{array}$ \\
\cline { 2 - 3 } & Sensual & $\begin{array}{l}\text { Intensity and craving for pleasure via } \\
\text { sights, smells, tastes, textures, and } \\
\text { sounds }\end{array}$ \\
\hline
\end{tabular}

Note. Adapted from Mendaglio (2012).

of characteristics gifted children bring to the development process. In some cases, all students who are gifted and talented are affected, but in others, only some are.

\section{Asynchronous Development}

All gifted children will experience some level of asynchronous development (see Chapter 4 for details), when their cognitive abilities develop out of sync with other dimensions of their development, such as their physical, social, and emotional abilities (Silverman, 2012). The asynchronies may be only minor, as in the child who begins to read at an early age, or dramatic, as in the child with verbal abilities at the college level while still an elementary student. The greater the asynchrony, the more difficulty the gifted child will have in negotiating Erikson's crises or determining what is an appropriate level of responsibility in the process of positive disintegration. Advanced cognitive abilities can lead adults interacting with gifted children to believe that they should have similarly advanced emotion regulation. When gifted children "act their age" emotionally, it may be seen as inappropriate behavior from someone who is cognitively advanced. Experiences that bring asynchronous development to the fore can influence the social and emotional development of gifted children.

\section{Personality}

Dabrowski was not alone in his interest in personality. In his early studies, Terman (1925) had a keen interest in the personality characteristics of gifted chil- 
dren. In his study of 1,528 geniuses (primarily Caucasian from professional class families), Terman found that they were well adjusted socially and possessed aboveaverage physical health, eagerness, and curiosity. Olszewski-Kubilius and Kulieke (1989) studied personality constellations in gifted youth and compared this group to a same-aged norming group. The gifted group had higher emotional stability, dominance, cheerfulness, conformity, warmth, and self-sufficiency, and lower apprehension and tension. The contemporary five-factor model-comprising neuroticism, extraversion, openness to experience, agreeableness, and conscientiousness-provides the most comprehensive theoretical framework for understanding the basic personality dimensions (McCrae \& Costa, 1996). Within the Big Five framework, intelligence has been documented to have the most consistent links to openness to experience and neuroticism. Higher intelligence and giftedness have been associated with a greater openness to new experiences (e.g., Goff \& Ackerman, 1992; Zeidner \& Shani-Zinovich, 2011) and, to some degree, with greater emotional stability (e.g., Ackerman \& Heggestad, 1997; DeYoung, 2011), and a preference for introversion (i.e., $47.7 \%$ gifted versus $35 \%$ nongifted; Sak, 2004).

Personality is an enduring, relatively stable endogenous characteristic. Educators of gifted children may expect a greater likelihood of introversion among their students. This tendency may best be served by allowing quiet spaces and times and reducing the overall level of stimulation for students who struggle with crowds, loud noises, and other stimuli. One can expect that introverted gifted individuals will not thrive in environments that are geared toward the majority of extroverts in modern U.S. society. However, there will be gifted young people who would be considered extroverts. Such personality differences should be not be ignored in education settings.

\section{Perfectionism}

Perfectionism is another endogenous characteristic, one that may interfere with the positive social and emotional development of gifted children. The construct of perfectionism has received considerable attention over the past 25 years. Conceptions of perfectionism have moved from a single-faceted, alwaysdetrimental phenomenon to a multifaceted phenomenon (see Fletcher \& Speirs Neumeister, 2012, for a review). Based on the substantial research base, it is clear that not all forms of perfectionism are negative. Speirs Neumeister (2015) emphasized the distinction between the two core factors of positive striving and evaluative concerns. Students with high levels of positive striving (self-oriented or adaptive or healthy perfectionists) often have similarly high levels of self-esteem and an internal locus of control (Speirs Neumeister, 2015). When paired with high levels of evaluative concern, however, the positive outcomes of self-oriented perfectionism turn negative. 
Perceived pressure from parents, teachers, and even peers to always be correct, to always be the best, can foster a belief that one must be perfect because others demand it. This socially prescribed perfectionism (Hewitt \& Flett, 1991) has been associated with multiple negative outcomes, including suicidal behaviors (Cross \& Cross, in press; Hewitt, Flett, \& Turnbull-Donovan, 1992). The perception that others expect perfection may not be accurate, but beliefs are an important driver of behaviors. When gifted young people come to believe that they are only valued to the extent that they perform, their academic goals may be based on a fear of failure. Not enjoying the learning process can cause students to underachieve, drop out of school, or pursue an easier path in school. All of these issues can make life as a gifted child in school very difficult.

\section{Excessive Self-Criticism}

Excessive self-criticism is a learned phenomenon wherein a person becomes too critical of him- or herself (Cross, 1997), typically related to a dissatisfaction with actual performance compared to an idealized performance. For example, it is not uncommon to witness a 7-year-old gifted child wad up a picture she is coloring and begin again because it is not as ideal as she envisioned. These experiences can create anger and frustration. An outcome of being excessively selfcritical is depression (Genshaft, Greenbaum, \& Borovsky, 1995; Webb, 1993). Because excessive self-criticism is learned, it can be unlearned. Professional counselors can be helpful in cognitive retraining, much as they might in the case of phobias.

\section{Multipotentiality}

Multipotentiality, having the potential to become exceptional at more than one thing, is a positive characteristic made problematic by its interactions within contexts. It has been seen as both a negative, when it becomes problematic for educational and social development (e.g., Delisle \& Squires, 1989; Kerr, 1991), and a positive, when it produces confidence and options (e.g., Sajjadi, Rejskind, \& Shore, 2001; Sosniak, 1985). The majority of the research has focused on the negative impact of multipotentiality and the difficulties caused by delay or inability to commit to a career path (Rysiew, Shore, \& Leeb, 1999).

When multiple talents become evident, the gifted child's family is often the first influence determining what talent the child values. One area of exceptional ability may be favored over another, or none of their potentials — or all—may be encouraged or discouraged. The financial and time costs of developing differing talents vary widely, so early decisions affect the family immensely. If the talent area is something that the local school develops, costs may be far less and more convenient relative to transportation and family commitment. Decisions to support the potential may need to be made early (e.g., violin) and may require considerable expertise on the part 
of the parent to nurture the student. Many of the same issues affect gifted children while they attend school. For example, becoming a basketball player may include early training in school, with more serious training out of school in the off-season. Training can often take place locally, whereas another domain, such as gymnastics, is typically taught outside of school and requires relatively expensive training and access to specific facilities often not located in the local community where the family lives. Thus, a person's talent domain may or may not be an issue based on access to facilities, experts, coaches and teachers, and practice time.

The more serious issues emerge when decisions favoring one area over the other are made. Societal prejudices may emerge, such as gender bias, racial bias, socioeconomic limitations, access issues, and so forth. In some cases, choices to develop a talent area are affected by society's prejudices. For example, boys becoming dancers or girls playing football are areas in which society's gender expectations limit opportunities. Students with multipotentiality may need more assistance to learn about career choices, with opportunities to shadow or intern as they explore their many options. Linking talent development opportunities to personal values, particularly as they relate to lifestyle preferences, can help multipotential gifted young people recognize priorities in choosing which talents to develop (Rysiew et al., 1999).

\section{On Being Gifted in School}

The previous descriptions of Erikson's (1963) Theory of Psychosocial Development and Dabrowski's (1964) Theory of Positive Disintegration and the endogenous characteristics of asynchronous development, personality, perfectionism, excessive self-criticism, and multipotentiality contribute to understanding of the social and emotional development of gifted young people. The picture is not complete, however, unless we consider exogenous (external) influences on their development. Schools, in particular, have great potential to affect students' social and emotional development.

\section{Complexities of Schools}

Because schools are inherently social enterprises that attempt to accommodate a very wide range of ages, many developmental stages, and a multitude of cultures, attending school as a gifted young person is inherently complicated. From teachers, principals, and counselors, to parents and even fellow students-nearly everyone holds deep-seated beliefs of giftedness that affect their interactions with gifted young people. Complicating matters even more is the fact that few educators are likely to have had training in gifted education. Consequently, being gifted in school settings tends to be replete with issues that may affect students' social and emotional development. 


\section{Lived Experience of Giftedness}

Schools are representative of the societies in which they exist. They serve as a society's primary institution for transmitting its culture. Intellectuals are often seen as challenging the dominant culture and social mores. The United States has been described as anti-intellectual, with schools reflecting that value (Howley, Howley, \& Pendarvis, 2017). With the mistrust of intellectuals generally and the antiintellectual nature of U.S. schools more specifically, being a gifted child can be complicated and confusing. Given the wide-ranging academic conceptions and implicit theories of giftedness, most gifted young people receive mixed messages about giftedness (Coleman \& Cross, 1988, 2000). As a result, a central component to the experience of being a gifted child is the need to determine the degree of acceptance and support one feels in the school environment, at home, at church, and so forth, and act in accordance. At times, the community's lack of support will conflict with a student's positive social and emotional development.

As gifted children mature into late elementary or middle school, social matters emerge as a central aspect of their development. Typically, the adults in their lives have taught them that differing environments require different comportment. For example, riding in elevators, attending church, or going to sports events requires/ tolerates differing manifestations of behavior. When young gifted children become more socially aware, they deal with typical psychosocial issues common to virtually all children in Western societies. The need to feel special while also needing to feel accepted as the same and the need to stand out while at the same time desiring to blend in are common issues of development. Being identified as gifted can limit the perceived acceptance and, therefore, social latitude these learners feel. This phenomenon has been titled the stigma of giftedness (Coleman, 1985; Coleman \& Cross, 1988, 2000), and the Stigma of Giftedness Paradigm (SGP) was created to study the phenomenon.

\section{Stigma of Giftedness Paradigm}

According to Coleman (1985, 2012), the Stigma of Giftedness Paradigm has three parts:

- Gifted students want to have normal social interactions.

- They learn that when others find out about their giftedness, they will be treated differently.

- They learn that they can manage information about themselves that will enable them to maintain a greater amount of social latitude.

As noted, gifted young people want normal social interactions. In this paradigm, there is not a generic expectation of normal. Introverted gifted students often pre- 
fer interactions with a single friend over large gatherings, whereas more extroverted gifted young people usually prefer the large gathering. Both situations would be normal. At home, gifted young people have been taught that it is appropriate to behave differently in differing situations. Gifted individuals do not want to lose social latitude, so they become aware of that possibility when others know about their exceptional abilities. Therefore, they determine that they can maintain the greatest degree of social latitude by managing the information they share with others.

Considerable research has been conducted on the lived experience of giftedness in school (Coleman, Micko, \& Cross, 2015). For example, the Information Management Model (IMM; Coleman \& Cross, 1988), shown in Figure 5.1, illustrates the social awareness of gifted children and how they attempt to develop the social latitude they desire. Children are acculturated to recognize that different environments have varied social expectations. The IMM describes the point at which a child enters these different environments and must make sense of them. At point " $A$ " the child feels different ("Yes") or does not feel different from peers ("No") in the environment. If he feels different, a choice is made at point " $\mathrm{B}$ " to manage information about the self to cope with the differentness ("Yes") or not ("No"). At point "C" we see a child engaging in various strategies such as those described below.

When asked if they feel different from or the same as their nongifted peers, more than $85 \%$ of gifted and talented students in Cross, Coleman, and TerhaarYonkers' (1991) study indicated feeling different. The same percentage of students reported that they manage information about themselves through social coping mechanisms. Among the few students who reported feeling the same as their nongifted peers, most also gave examples of how they were, in fact, different. The same pattern emerged when they were asked if they managed information about themselves. After saying that they did not, virtually all gave examples of social coping behavior (Coleman \& Cross, 1988). Denial of differences is inherently a coping behavior. These interviews with the gifted students led to the creation of the IMM.

From gifted young people's responses to questions, the researchers learned that the social goals they create for themselves fell into one of three categories: Standing Out, Invisibility, or Disidentifying. These categories of social goals were established as a continuum of visibility (Coleman \& Cross, 1988; see Figure 5.2). Among the gifted young people who felt different and had managed information, all desired to reach one of these three social goal categories.

Cross and colleagues (1991) estimated that fewer than 5\% of gifted students attempt to bring attention to themselves as gifted- "Standing Out." The second goal is to be Invisible among the school population, to blend in with others. This is done by wearing popular clothes, listening to popular music, talking like others, and so forth. Cross et al. estimated that approximately $70 \%$ of gifted individuals desire to blend in. Common strategies for becoming invisible include not admitting that 


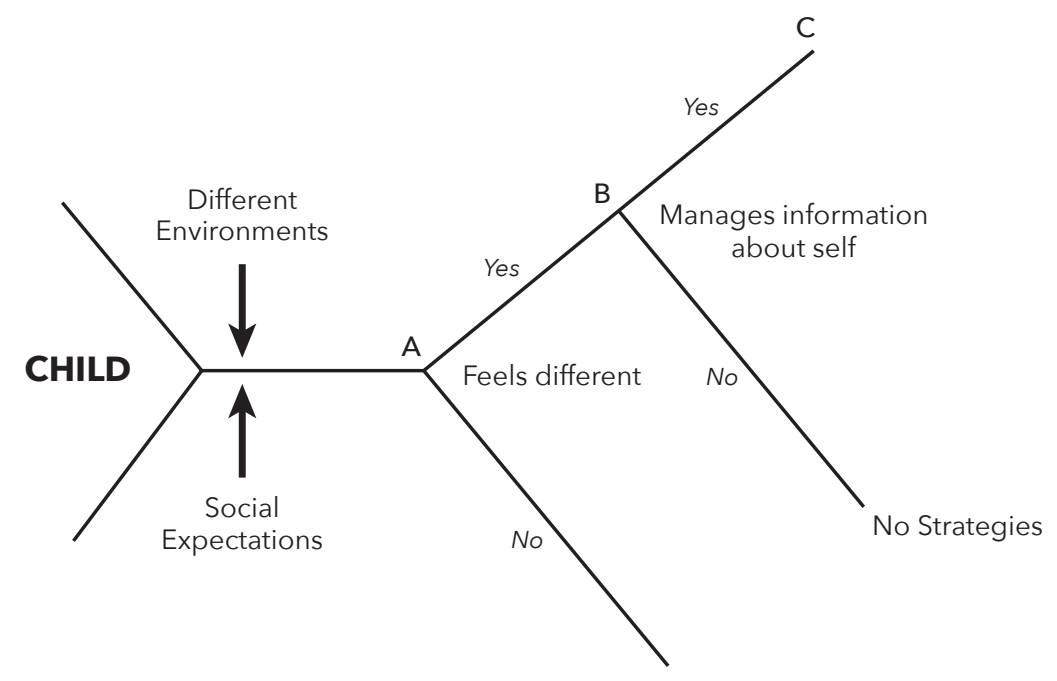

Figure 5.1. Information Management Model. From "Is being gifted a social handicap?" (p. 44) by L. J. Coleman and T. L. Cross, 1988, Journal for the Education of the Gifted, 11. Copyright 1988, The Association for the Gifted. Reprinted with permission of the author.

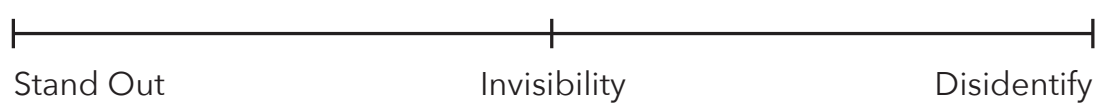

Figure 5.2. Continuum of visibility.

a test was easy, not volunteering answers, missing a few items on a test, and when asked about accomplishments, being noncommittal (Coleman, 1985).

The last goal on the continuum is to Disidentify with gifted students. An estimated $25 \%$ of gifted individuals who engage in social coping hold this goal (Cross et al., 1991). To that end, one can hang around groups of students who in the school would be stereotyped as not being gifted. Other social coping behaviors engaged in to reach this goal include telling jokes, claiming a test was difficult, feigning interest in small talk, making fun of other gifted kids, and going out for extracurricular activities for which one has little talent (Coleman, 1985).

In sum, due to the very complicated social environment of schools relative to giftedness, most gifted young people engage in social coping behaviors to create and maintain the social latitude to which they aspire. Most of the behaviors are relatively innocuous, although some are negative and a few possibly positive. Hiding oneself, 
avoiding interactions, and avoiding working on passions can be harmful in the social development of the gifted young person. Standing out somewhat brazenly as one who enjoys learning carries with it considerable social sanctions, as these gifted individuals are often made fun of or not included in social opportunities. Therefore, these behaviors may stifle social development. Some coping behaviors can have positive outcomes. For example, reading more in lieu of other experiences may become a lifetime recreation of choice, leading to increasing knowledge and enjoyment. When the environment is accepting of differences, including differences in academic ability, learners who are gifted and talented will not need to alter their behaviors to find the positive social experiences all children need.

\section{Conclusion}

Although they may be exceptional in their interests and abilities, gifted children are children first. All children need to feel connected to others, need opportunities to explore their interests, and need to find out what they can do (Deci \& Ryan, 2000). Erikson's (1963) theory of psychosocial development applies to all learners, but it must be interpreted in the context of a child developing with exceptional abilities. Dabrowski's (1964) Theory of Positive Disintegration attempts to explain development of gifted individuals. The endogenous characteristics of asynchronous development, personality, perfectionism, excessive self-criticism, and multipotentiality are unique to this population. Only by recognizing the significance of their exceptionalities in context can educators adequately support the social and emotional development of students with gifts and talents.

\section{Big Ideas}

1. Gifted children will experience the same psychosocial crises as their nongifted peers. They may encounter these crises earlier.

2. Gifted children may relate their own experiences to the Theory of Positive Disintegration as they go through the stages of personality development.

3. All gifted children will exhibit some form of asynchronous development. The greater the asynchrony, the greater the challenges to their social and emotional development.

4. A higher proportion of gifted children than their nongifted peers has a tendency toward introversion. Their preference for reduced stimulation may be misunderstood by more extroverted peers and adults. 


\section{Big Ideas, Continued.}

5. Being overly concerned with the perceived opinions of others affects the social and emotional development of gifted young people.

6. Multipotentiality can create a dilemma for the child, particularly when choices must be made to pursue one activity over other, equally attractive options.

7. Gifted children often receive mixed messages from teachers, counselors, and school administrators about their exceptional abilities.

8. Gifted children need positive social interactions; the Stigma of Giftedness Paradigm argues that they sometimes choose to manage the information others have about their exceptional abilities in order to have what they perceive as normal interactions.

\section{Discussion Questions}

1. Quite often people use the terms social and emotional as a single construct. How do you distinguish between the two? Are they equally important in the well-being of gifted students?

2. We have learned that people continue to develop over time. We have also learned of the construct of asynchronous development. What are some of the common ways in which students with gifts and talents are affected by asynchronous developmental patterns? How can these affect the classroom?

3. Have you ever received mixed messages from people about giftedness and gifted people? If so, how did you feel about it? Now, imagine a 15-year-old girl who faces these mixed messages on a daily basis. Add gender expectations, expectations associated with ethnicity, and the perceived expectations for consistent excellent performance in school. What steps might she take to create a reasonable life for herself?

4. Quite often adults talk about what they enjoy doing and are good at. For example, fishing, camping, cooking, sewing, athletic activities, and so forth are common hobbies. Often missing from this list are academic examples. Why might that be the case? What are some of the ramifications of this for the adults and for their children? 


\section{Discussion Questions, Continued.}

5. Despite the numerous ways in which children vary (e.g., motivation, personality, passions, psychosocial development), some will argue it is in the students' interest to treat them exactly the same. Do you agree? Is sameness fairness? Is sameness equitable?

6. Everyone has to wait as part of existing within differing social contexts. How much waiting in classrooms is acceptable for students? Is the onus on the students to entertain themselves during periods of waiting in school? What are the long-term effects of spending much of your in-class time waiting for an appropriate assignment or opportunity?

7. Many adults think that students with gifts or talents are nerdy, some adults think that they are pushy, and still other adults think that they do not exist. If you were invited to serve on a panel during a meeting of faculty in a middle school, and your charge was to describe the daily experience of students with gifts and talents, what might you emphasize? What if you were to answer the same prompt, but in an assembly of middle school students of all abilities?

\section{References}

Ackerman, P. L., \& Heggestad, E. D. (1997). Intelligence, personality, and interests: Evidence for overlapping traits. Psychological Bulletin, 121, 219-245.

Cohen, J., Onunaku, N., Clothier, S., \& Poppe, J. (2005). Helping young children succeed: Strategies to promote early childhood social and emotional development. Washington, DC: National Conference of State Legislatures and Zero to Three. Coleman, L. J. (1985). Being gifted in school. Menlo Park, NJ: Addison-Wesley.

Coleman, L. J. (2012). Lived experience, mixed messages, and stigma. In T. L. Cross \& J. R. Cross (Eds.), Handbook for counselors serving students with gifts and talents: Development, relationships, school issues, and counseling needs/interventions (pp. 371-302). Waco, TX: Prufrock Press

Coleman, L. J., \& Cross, T. L. (1988). Is being gifted a social handicap? Journal for the Education of the Gifted, 11, 41-56.

Coleman, L. J., \& Cross, T. L. (2000). Social-emotional development and personal experience. In K. Heller, F. J. Mönks, R. J. Sternberg, \& R. S. Subotnik (Eds.), International handbook of giftedness and talent (2nd ed., pp. 203-212). Oxford, UK: Pergamon. 
Coleman, L. J., Micko, K. J., \& Cross, T. L. (2015). Twenty-five years of research on the lived experience of being gifted in school: Capturing the students' voices. Journal for the Education of the Gifted, 38, 358-376.

Cross, T. L. (1997). Psychological and social aspects of educating gifted students. The Peabody Journal of Education, 72(3-4), 181-201.

Cross, T. L., Coleman, L. J., \& Terhaar-Yonkers, M. (1991). The social cognition of gifted adolescents in schools: Managing the stigma of giftedness. Journal for the Education of the Gifted, 15, 44-55.

Cross, T. L., \& Cross, J. R. (in press). Suicide among students with gifts and talents. In S. Pfeiffer, M. Foley-Nicpon, \& E. Shaunessy-Dedrick (Eds.), American Psychological Association handbook of giftedness and talent. Washington, DC: American Psychological Association.

Dabrowski, K. (1964). Positive disintegration. Boston, MA: Little, Brown.

Deci, E. L., \& Ryan, R. M. (2000). The "what" and "why" of goal pursuits: Human needs and the self-determination of behavior. Psychological Inquiry, 11, 227-268.

Delisle, J. R., \& Squires, S. (1989). Career development for gifted and talented youth: Division on Career Development (DCD) and The Association for the Gifted (TAG) position statement. Journal for Education of the Gifted, 13, 97-104.

DeYoung, C. G. (2011). Intelligence and personality. In R. J. Sternberg \& S. B. Kaufman (Eds.), The Cambridge handbook of intelligence (pp. 711-737). New York, NY: Cambridge University Press.

Erikson, E. H. (1963). Childhood and society (2nd ed.). New York, NY: Norton.

Fletcher, K. L., \& Speirs Neumeister, K. L. (2012). Research on perfectionism and achievement motivation: Implications for gifted students. Psychology in the Schools, 49, 668-677.

Genshaft, J. L., Greenbaum, S., \& Borovsky, S. (1995). Stress and the gifted. In J. L. Genshaft, M. Bireley, \& C. L. Hollinger (Eds.), Serving gifted and talented students: A resource for school personnel (pp. 257-268). Austin, TX: Pro-Ed.

Goff, M., \& Ackerman, P. L. (1992). Personality-intelligence relations: Assessment of typical intellectual engagement. Journal of Educational Psychology, 84, $537-553$.

Hewitt, P. L., \& Flett, G. L. (1991). Perfectionism in the self and social contexts: Conceptualization, assessment, and association with psychopathology. Journal of Personality and Social Psychology, 60, 456-470.

Hewitt, P. L., Flett, G. L., \& Turnbull-Donovan, W. (1992). Personality and suicidal intent. British Journal of Clinical Psychology, 31, 181-190.

Howley, C., Howley, A., \& Pendarvis, E. (2017). Out of our minds: Turning the tide of anti-intellectualism in American schools (2nd ed.). Waco, TX: Prufrock Press. Kerr, B. A. (1991). A handbook for counseling the gifted and talented. Alexandria, VA: American Association for Counseling and Development. 
McCrae, R. R., \& Costa, P. T., Jr. (1996). Toward a new generation of personality theories: Theoretical contexts for the five-factor model. In J. S. Wiggins (Ed.), The five-factor model of personality: Theoretical perspectives (pp. 51-87). New York, NY: Guilford.

Mendaglio, S. (2012). Overexcitabilities and giftedness research: A call for a paradigm shift. Journal for the Education of the Gifted, 35, 207-219.

Mendaglio, S., \& Tillier, W. (2006). Dabrowski's theory of positive disintegration and giftedness: Overexcitability research findings. Journal for the Education of the Gifted, 30, 68-87.

Olszewski-Kubilius, P., \& Kulieke, M. J. (1989). Personality dimensions of gifted adolescents. In J. L. VanTassel-Baska \& P. Olszewski-Kubilius (Eds.), Patterns of influence on talent development: The home, the self and the school (pp. 125-145). New York, NY: Teachers College Press.

Rysiew, K. J., Shore, B. M., \& Leeb, R. T. (1999). Multipotentiality, giftedness, and career choice: A review. Journal of Counseling and Development, 77, 423-430.

Sajjadi, S. H., Rejskind, F. G., \& Shore, B. M. (2001). Is multipotentiality a problem or not? A new look at the data. High Ability Studies, 12, 27-43.

Sak, U. (2004). A synthesis of research on psychological types of gifted adolescents. Journal of Secondary Gifted Education, 15, 70-79.

Silverman, L. K. (2012). Asynchronous development: A key to counseling the gifted. In T. L. Cross \& J. R. Cross (Eds.), Handbook for counselors serving students with gifts and talents: Development, relationships, school issues, and counseling needs/ interventions (pp. 261-279). Waco, TX: Prufrock Press.

Sosniak, L. A. (1985). Becoming an outstanding research neurologist. In B. S. Bloom (Ed.), Developing talent in young people (pp. 348-408). New York, NY: Ballantine.

Speirs Neumeister, K. L. (2015). Perfectionism in gifted students. In M. Neihart, S. Pfeiffer, \& T. L. Cross (Eds.), Social and emotional development of gifted children (2nd ed., pp. 29-39). Waco, TX: Prufrock Press.

Terman, L. (1925). Genetic studies of genius: Vol. 1. Mental and physical traits of a thousand gifted children. Stanford, CA: Stanford University Press.

Tillier, B. (1995). The theory of positive disintegration by Kazimierz Dabrowski. Retrieved from http://www.positivedisintegration.com/10concepts.html\#ml

Tillier, W. (2009). Dabrowski without the theory of positive disintegration just isn't Dabrowski. Roeper Review, 31, 123-126.

Webb, J. T. (1993). Nurturing social-emotional development of gifted children. In K. A. Heller, F. J. Mönks, \& A. H. Passow (Eds.), International handbook of research and development of giftedness and talent (pp. 525-538). Oxford, UK: Pergamon Press. 
Zeidner, M., \& Shani-Zinovich, I. (2011). Do academically gifted and nongifted students differ on the Big-Five and adaptive status? Some recent data and conclusions. Personality and Individual Differences, 51, 566-570. 